\title{
Physical map of the aromatic amine and $m$-toluate catabolic plasmid pTDN1 in Pseudomonas putida: location of a unique meta-cleavage pathway
}

\author{
Christopher P. Saint, ${ }^{*} \dagger$ Nicholas C. McClure and W. A. Venables \\ School of Pure and Applied Biology, South Wing, University of Wales College of Cardiff, Cardiff CF1 3TL, UK
}

(Received 2 October 1989; revised 28 November 1989; accepted 5 January 1990)

\begin{abstract}
A restriction endonuclease map was derived for the aromatic amine and $m$-toluate catabolic plasmid pTDN1 present in Pseudomonas putida UCC22, a derivative of $P$. putida $\mathrm{mt}-2$. The plasmid is $79 \pm 1 \mathrm{kbp}$ in size and can be divided into a restriction-site-deficient region of $51 \pm 1 \mathrm{kbp}$ and a restriction-site-profuse region of $28 \mathrm{kbp}$ which begins and ends with directly repeating sequences of at least $2 \mathrm{kbp}$ in length. A mutant plasmid isolated after growth of the host on benzoate had lost the restriction-profuse region by a straightforward recombinational loss retaining one copy of the direct repeat. Analysis of clones, deletion and Tn5 insertion mutants strongly suggested that the meta-cleavage pathway of pTDN1 was situated in the region readily deleted. The catechol 2,3-dioxygenase (C23O) gene of pTDN1 showed no hybridization or restriction homology to previously described C23O genes of TOL plasmids pWW0 and pWW15. In addition, there was little homology between intact pTDN1, pWWO and pWW15, suggesting the presence of a unique meta-cleavage pathway. We also demonstrated that pTDN1 did not originate from $P$. putida $\mathrm{mt}-2$ chromosome.
\end{abstract}

\section{Introduction}

Anilines and ring-substituted anilines are major products of herbicide metabolism in the soil. Isolation and construction of bacterial strains for the biodegradation of these potential environmental pollutants is of significant interest.

Plasmid-encoded degradation of aniline was first reported by Anson \& Mackinnon (1984) but genetical and physical characterization of the plasmid was not done. The only other aromatic-amine-degrading plasmid was reported by McClure \& Venables (1986). This latter plasmid was discovered after the adaptation of Pseudomonas putida mt-2 (ATCC 33015) to growth on the aromatic amines aniline and $m$ - and $p$-toluidine. P.putida $\mathrm{mt}-2$ carries TOL plasmid $\mathrm{pWW} 0$ which encodes the degradation of toluene and $m$ - and $p$-xylene via benzoate, $m$-toluate and $p$-toluate respectively (Williams \& Murray, 1974; Worsey \& Williams, 1975). The adapted strain

$\dagger$ Present address: Department of Plant Pathology, Waite Agricultural Research Institute, University of Adelaide, Glen Osmond, Adelaide, South Australia 5064, Australia.

Abbreviations: C23O, catechol 2,3-dioxygenase; DHCDH, dihydroxycyclohexadiene carboxylate dehydrogenase; TO, toluidine oxygenase.
UCC2 contained a derivative of pWW0 deleted of its catabolic genes, plus a novel plasmid designated pTDN1. Additionally, UCC2 retained the ability to grow on $m$-toluate and coupled with aromatic amine degradation this was termed the $\mathrm{Tdn}^{+}$phenotype (McClure \& Venables, 1986). Data from oxygen uptake experiments, release of ammonia by UCC2 incubated with aniline or $m$ - or $p$-toluidine, identification of metacleavage products and induction profiles of the relevant meta-cleavage enzymes indicated a pathway analogous to the TOL meta-cleavage pathway incorporating a toluidine oxygenase (TO) (Fig. 1; McClure \& Venables, 1986). Subsequently, the deleted derivative of pWW0 was removed with no loss of phenotype to give strain UCC2-2; pTDN1 was found to be conjugative, yielding a $\mathrm{Tdn}^{+}$phenotype in transconjugants, and a catechol 2,3dioxygenase $(\mathrm{C} 23 \mathrm{O})$ gene was cloned from pTDN1 and its expression investigated (McClure \& Venables, 1987). pTDN1 showed no restriction homology to $\mathrm{pWW} 0$ and it was proposed that its appearance during the adaptation of strain mt-2 may have been due to its emergence from a cryptic chromosomally integrated state.

This paper describes a complete restriction map for pTDN1 and the results of growth on benzoate, which produces a $\mathrm{Tdn}^{-}$phenotype resulting from a recombina- 


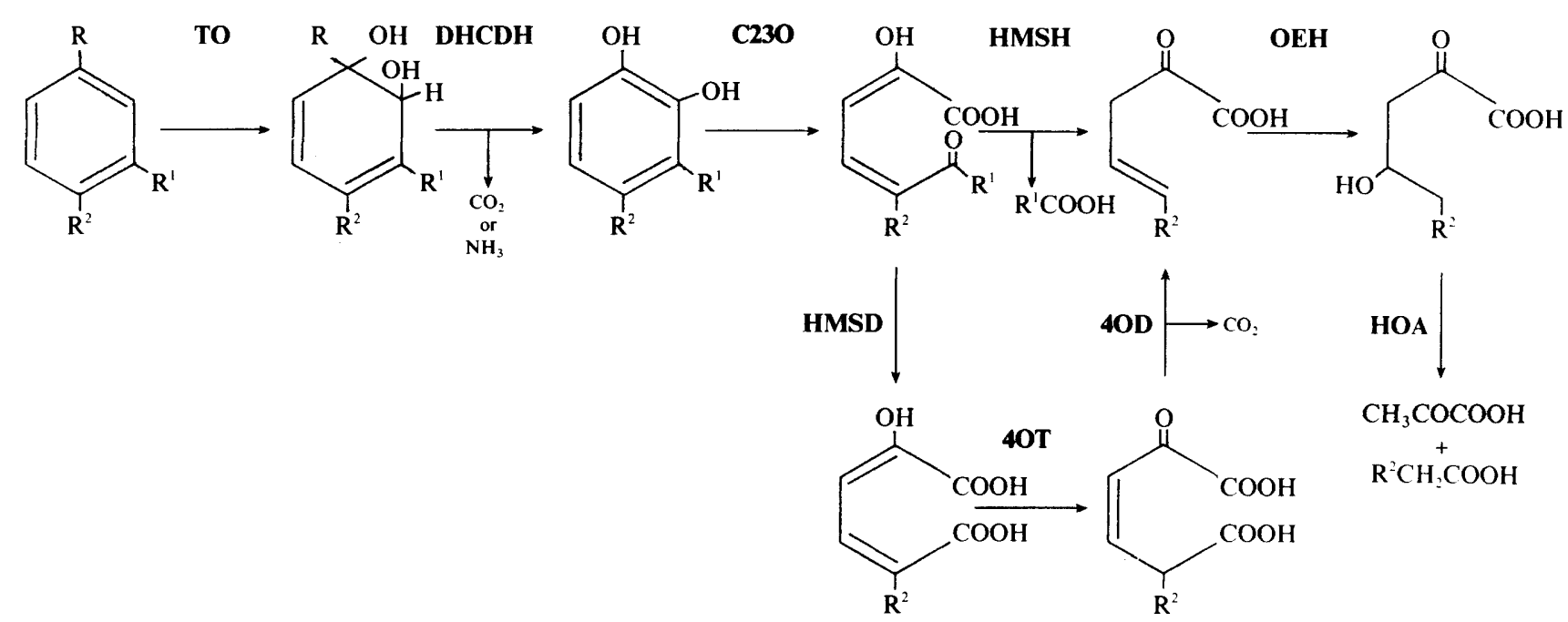

Fig. 1. Proposed pathway of aromatic amine and $m$-toluate dissimilation by $P$. putida $\mathrm{UCC} 22 . \mathrm{R}=\mathrm{NH}_{2}, \mathrm{R}^{1}=\mathrm{H}$ and $\mathrm{R}^{2}=\mathrm{H}$, aniline; $\mathbf{R}=\mathrm{NH}_{2}, \mathbf{R}^{1}=\mathrm{CH}_{3}$ and $\mathbf{R}^{2}=\mathrm{H}, m$-toluidine $\mathbf{R}=\mathbf{N H}_{2}, \mathbf{R}^{1}=\mathbf{H}$ and $\mathbf{R}^{2}=\mathbf{C H}_{3}, p$-toluidine $\mathbf{R}=\mathbf{C O O H}, \mathbf{R}^{1}=\mathbf{H}$ and $\mathbf{R}^{2}=\mathbf{H}$, benzoate; $R=\mathrm{COOH}, \mathbf{R}^{1}=\mathrm{CH}_{3}$ and $\mathbf{R}^{2}=\mathrm{H}, m$-toluate. TO, toluidine oxygenase; $\mathrm{DHCDH}$, dihydroxycyclohexadiene carboxylate dehydrogenase; $\mathrm{C23O}$, catechol 2,3-dioxygenase; HMSH, 2-hydroxymuconic semialdehyde hydrolase; HMSD, 2-hydroxymuconic semialdehyde dehydrogenase; 4OT; 4-oxalocrotonate tautomerase; 4OD, 4-oxalocrotonate decarboxylase; OEH, 2-oxo-4-pentenoate hydratase; HOA, 2-oxo-4-hydroxypentenoate aldolase.

tional loss of plasmid DNA between two directly repeating regions approximately $24 \mathrm{kbp}$ apart. We also further characterized the $\mathrm{C} 23 \mathrm{O}$ gene of pTDN1 which appears to form part of a unique meta-cleavage pathway for the degradation of $m$-toluate, benzoate and aromatic amines. Additionally, we demonstrate that pTDN1 did not arise from the chromosome of strain $\mathrm{mt}-2$ and is in no way derived from $\mathrm{pWW} 0$; we speculate on the origin of this plasmid.

\section{Methods}

Bacterial strains and plasmids. The Pseudomonas putida and Escherichia coli strains and the plasmids used and constructed during the course of this investigation are detailed in Table 1.

Media and culture conditions. Nutrient agar and nutrient broth were prepared according to the manufacturers' instructions (Difco). Solid and liquid minimal media were prepared with previously described supplements (Eaton \& Ribbons, 1982). To ensure maintenance of recombinant plasmids streptomycin $\left(25 \mu \mathrm{g} \mathrm{ml}^{-1}\right)$, for $\mathrm{pKT} 231$ derivatives, and ampicillin $\left(100 \mu \mathrm{g} \mathrm{ml}^{-1}\right)$, for pHG327 and pBR322 derivatives, were added to media. Transposon insertion mutants were maintained with kanamycin $\left(25 \mu \mathrm{g} \mathrm{ml}^{-1}\right)$, for $\mathrm{Tn} 5$, and rifampicin $\left(100 \mu \mathrm{g} \mathrm{ml}^{-1}\right)$ for $P$. putida K T2442 background. Retention of pNJ5000 was achieved by addition of tetracycline $\left(10 \mu \mathrm{g} \mathrm{ml}^{-1}\right)$. Carbon source was at $5 \mathrm{mM}$ concentration in minimal media, pTDN1-containing strains being maintained on $p$-toluidine and aniline and $\mathrm{TOL}^{+}$strains on $m$-toluate.

Chromosomal DNA extraction. P. putida strains were incubated overnight, with shaking, in $200 \mathrm{ml}$ of minimal medium containing $10 \mathrm{~mm}$-acetate and $0.05 \%$ (w/v) Casamino acids. Cells were collected by centrifugation at 6000 r.p.m. for $20 \mathrm{~min}$ and the pellet resuspended in $30 \mathrm{ml} 25 \%(\mathrm{w} / \mathrm{v})$ sucrose prepared in $50 \mathrm{~mm}-\mathrm{Tr}$ is $/ \mathrm{HCl}, \mathrm{pH} 8$. Cell suspension $(15 \mathrm{ml})$ was then mixed with $1 \mathrm{ml}$ lysozyme $\left(5 \mathrm{mg} \mathrm{ml}^{-1}\right)$ and left at room temperature for $2-3 \mathrm{~min} ; 2.5 \mathrm{ml} 250 \mathrm{mM}$-EDTA (pH 8) was added and the suspension mixed carefully and left a further $2-3 \mathrm{~min}$; $2.5 \mathrm{ml}$ SDS $(20 \%, \mathrm{w} / \mathrm{v}$, in $50 \mathrm{~mm}-\mathrm{Tris} / \mathrm{HCl}, \mathrm{pH} 8)$ was added, carefully mixed, and left for 2-3 min. An equal volume of a mixture of $50 \%(\mathrm{v} / \mathrm{v})$ phenol in chloroform was added and the lysate immediately centrifuged at 15000 r.p.m. for $30 \mathrm{~min}$. As much of the upper aqueous phase as possible was carefully removed using a wide outlet plastic pipette. $\mathrm{CsCl}$ was carefully dissolved in an appropriate volume of extract and chromosomal DNA purified by density-gradient centrifugation at 40000 r.p.m. (Sorvall TV-865B rotor) for 48 h. After ethidium bromide extraction and suitable dialysis of the DNA the result was a concentrated (up to $1 \mu \mathrm{g} \mu \mathrm{l}^{-1}$ ) high-molecular-mass sample suitable for restriction digestion.

Plasmid DNA extraction and manipulation. Presumptive $\mathrm{Tn} 5$ insertion mutants were screened using the procedure of Birnboim \& Doly (1979); detailed analysis was done on plasmid DNA extracted by the procedure of Wheatcroft \& Williams (1981). Screening for the presence of recombinant plasmids was done according to Holmes \& Quigley (1981) and vector and cloned DNA prepared in quantity by $\mathrm{CsCl} /$ ethidium bromide density-gradient centrifugation of cleared lysates (Guerry et al., 1973). Restriction endonuclease digestion and ligation with T4 ligase were done according to the manufacturer's (NBL) instructions. E. coli strains were transformed by standard procedures (Cohen et al., 1972) and transformants selected on media containing an appropriate antibiotic for vector selection.

Production of transposon insertion mutants. E. coli ED2196 containing pLG221 was conjugated on a $0.45 \mu \mathrm{m}$ Millipore filter with UCC22. $\mathrm{Tdn}^{+} \mathrm{Km}^{\mathrm{r}}$ transconjugants were selected. pLG221 is not stably maintained outside enteric bacteria (Boulnois et al., 1985), therefore transconjugants were derivatives of UCC22 with $\mathrm{Tn} 5$ in the chromosome or pTDN1. A selection of transconjugants were rapidly screened by direct plate conjugation with $P$. putida KT2442 selecting for transfer of $\mathrm{Km}^{\mathrm{r}}$ to reveal the sites of Tn5 insertion. pTDN1 transfers to KT2442 at a frequency $>1 \times 10^{-4}$ per donor. Twelve donors which yielded transconjugants at an appreciably lower rate than 
Table 1. Bacterial strains and plasmids

Abbreviations: $\mathrm{Tdn}^{+}$, ability to grow on aromatic amines and $m$-toluate; $\mathrm{Lac}^{+}$, growth on lactose; Rif, rifampicin; Tc, tetracycline; Sm, streptomycin; Km, kanamycin; Ap, ampicillin; C230, catechol 2,3-dioxygenase. For designations of restriction fragments (XC, $\mathrm{HB}$ etc.) see Table 2 and Fig. 2.

\begin{tabular}{|c|c|c|}
\hline Strain & Plasmid & Notes and reference \\
\hline \multicolumn{3}{|c|}{ P. putida $\mathrm{mt}-2$} \\
\hline $\mathrm{UCC} 22$ & pTDN1 & Formerly UCC2-2 (McClure \& Venables, 1987) Tdn+ (McClure \& Venables, 1986) \\
\hline $\mathrm{UCC} 23$ & pTDN1-3 & Tdn- deleted derivative isolated after growth on benzoate (this study) \\
\hline KT2440 & - & Franklin et al. (1981) \\
\hline KT2442 & - & KT2440 Rif (Franklin et al., 1981) \\
\hline PaW1 & pWW0 & $\mathrm{TOL}^{+}$(Murray et al., 1972; Williams \& Murray, 1974) \\
\hline PaW130 & - & TOL-Rif (Keil et al., 1985b). \\
\hline \multicolumn{3}{|l|}{ P. putida } \\
\hline MT15 & pWW 15 & TOL $^{+}($Keil \& Williams, 1985) \\
\hline \multicolumn{3}{|l|}{ E. coli } \\
\hline \multirow{2}{*}{ SK 1592} & - & Kushner (1978) \\
\hline & pTDN1-1000 & $\mathrm{C}^{230^{+}}$formerly pNCM1. XB of pTDN1 cloned into pKT231 (McClure \& Venables, 1987) \\
\hline \multirow[t]{10}{*}{ C600 } & - & Bachmann (1987) \\
\hline & pNJ5000 & $\mathrm{Tc}^{\mathrm{r}}$ unstable derivative of RP4 (Grinter, 1983) \\
\hline & pKT231 & $\mathrm{Sm}^{r} \mathrm{Km}^{r}$ (Bagdasarian et al., 1981) \\
\hline & pTDN1-1002 & $\mathrm{XC}$ of pTDN1 in pKT231 (this study) \\
\hline & pTDN1-1004 & XD of pTDN1 in pKT231 (this study) \\
\hline & pTDN1-1006 & XE of pTDN1 in pKT231 (this study) \\
\hline & pTDN1-1014 & HB of pTDN1 in pKT231 (this study) \\
\hline & pTDN1-1015 & HB of pTDN1 in opposite orientation to pTDN1-1014 (this study) \\
\hline & pTDN1-1016 & HC of pTDN1 in pKT231 (this study) \\
\hline & pTDN1-1020 & EC of pTDN1 in pKT231 (this study) \\
\hline \multirow[t]{6}{*}{ JM107 } & - & Lac $^{-}$host strain for transformation involving pHG327 (Yanisch-Perron et al., 1985) \\
\hline & pHG327 & $\mathrm{Lac}^{+} \mathrm{Ap}^{\mathrm{r}}$ (Stewart et al., 1986) \\
\hline & pTDN1-1010 & HD of TDN1 in pHG327 (this study) \\
\hline & pTDN1-1011 & HD of pTDN1 in opposite orientation to pTDN1-1010 (this study) \\
\hline & pTDN1-1018 & $\begin{array}{l}\text { pTDN1-1011 digested with } S s t I \text { and religated to leave a } 2 \cdot 1 \mathrm{kbp} \text { SstI-HindIII fragment derived } \\
\text { from HD (this study) }\end{array}$ \\
\hline & pTDN1-1012 & HE of pTDN1 in pHG327 (this study) \\
\hline \multirow[t]{3}{*}{ PM191 } & - & C600 recA (Keil et al., 1985a) \\
\hline & pWW15-3151 & $\mathrm{Xh}(\mathrm{C} 23 \mathrm{OI})$ fragment of pWW15 in pKT230 (Keil et al., 1985a) \\
\hline & pWW15-3161 & $\mathrm{Bj}(\mathrm{C} 23 \mathrm{OII})$ fragment of pWW15 in pBR322 (Keil et al., 1985a) \\
\hline \multirow{2}{*}{ ED2196 } & - & Gasson \& Willetts (1977) \\
\hline & pLG221 & $\operatorname{Tn} 5$ donor $\mathrm{Km}^{\mathrm{r}}$ (Boulnois et al., 1985) \\
\hline
\end{tabular}

this $\left(<10^{-6}\right.$ per donor) were retained and assumed to contain $\operatorname{Tn} 5$ in the chromosome due to the low rate of transfer. Such donors yield a variety of pTDN1::Tn5 insertion mutants on conjugation, whereas donors with $\mathrm{Tn} 5$ already present in pTDN1 give identical transconjugants.

DNA-DNA hybridization. Restriction fragments were separated by agarose gel electrophoresis and transferred by Southern blotting (Southern, 1975) to Biodyne filter membranes (Pall Ultrafine Filtration Corp.). Radiolabelled probes were prepared by nick-translation incorporating $\left[\alpha^{-32} \mathrm{P}\right] \mathrm{dCTP}$ using a preparative kit (BRL-Gibco) and probe purified by elution through Sephadex G-50. Hybridizations were done using a PR800 Hybride-Ease Hybridization Chamber (Hoefer Scientific Instruments) at $65^{\circ} \mathrm{C}$ using the manufacturer's protocol. Hybridization stringency was controlled by using low $(2 \times$ SSPE, $1 \%$, $\mathrm{w} / \mathrm{v}, \mathrm{SDS})$, moderate $(0.5 \times \operatorname{SSPE}, 1 \%, \mathrm{w} / \mathrm{v}, \mathrm{SDS})$ and high $(0.1 \times$ SSPE, $1 \%, w / v$, SDS) stringency washes consecutively for $30 \mathrm{~min}$, each at $65^{\circ} \mathrm{C}$. $\left(2 \times\right.$ SSPE is $300 \mathrm{~mm}-\mathrm{NaCl}, 20 \mathrm{~mm}-\mathrm{NaH}_{2} \mathrm{PO}_{4}, 2 \mathrm{~mm}-$ $\mathrm{Na}_{2}$ EDTA, pH 7.4). Where homology of pTDN1 and its $\mathrm{C} 23 \mathrm{O}$ gene to TOL plasmids, C23OI and C23OII and chromosomal DNA was investigated only a low stringency wash was used. For all other hybridizations low, moderate and high stringency washes were used. Autoradiography was done using Kodak XRP film; film and filter were sandwiched between two Phillips intensifying screens in a Kodak cartridge at $-70^{\circ} \mathrm{C}$.

Catechol spray test. This was done as described by Franklin $e t$ al. (1981).

Mobilization using $p N J 5000$. Triparental conjugations were done on $0.45 \mu \mathrm{m}$ Millipore membranes involving $E$. coli C600(pNJ5000), $P$. putida KT2442 and C600 containing pTDN1-1014 or pTDN1-1015. After incubation, mixtures were resuspended in $0.95 \%(\mathrm{w} / \mathrm{v}) \mathrm{NaCl}$ and plated to aniline minimal medium supplemented with rifampicin $\left(100 \mu \mathrm{g} \mathrm{ml}^{-1}\right)$.

\section{Results}

\section{Restriction map of pTDNI}

A complete restriction map is given in Fig. 2, and fragment sizes for the enzymes HindIII, XhoI, EcoRI, BamHI, SalI and SmaI, in Table 2. A combination of 


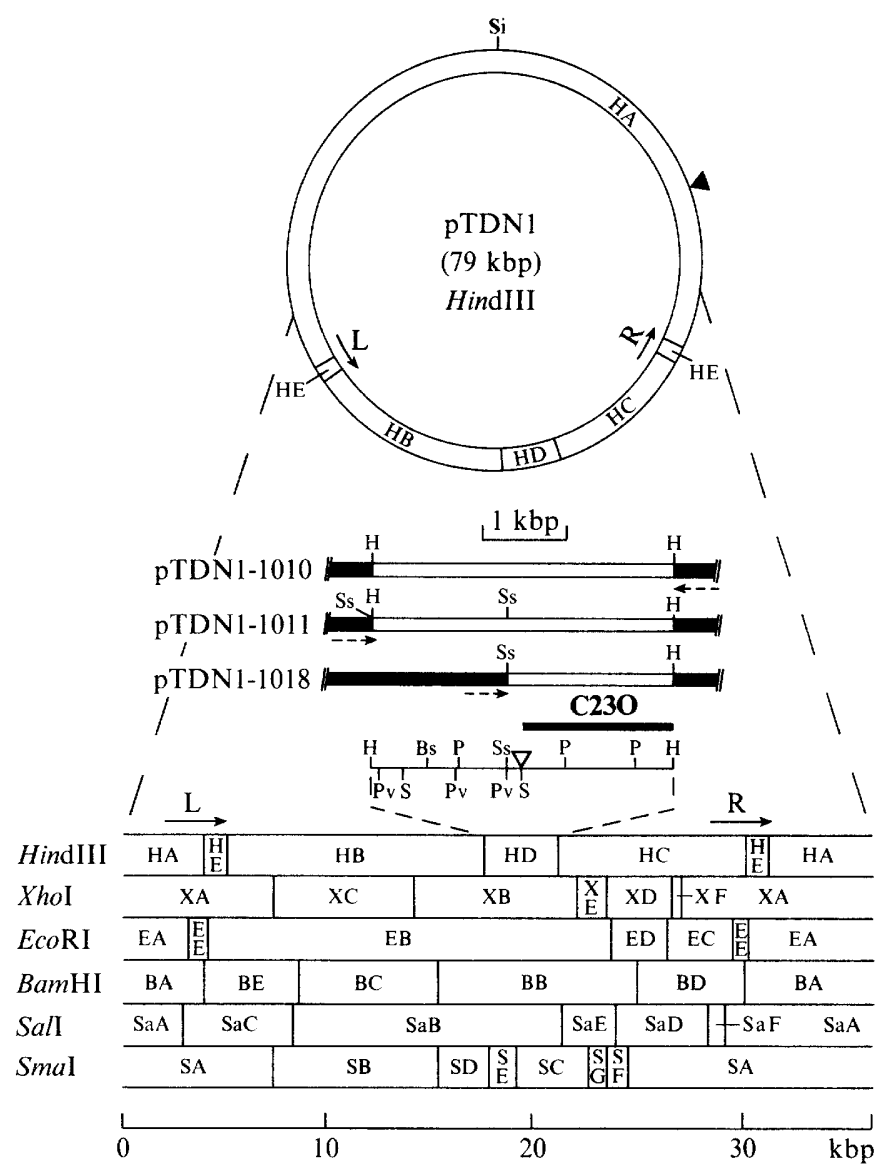

Fig. 2. Restriction endonuclease map of pTDN1 and positioning of a $\mathrm{C} 23 \mathrm{O}$ gene. Arrows indicate the known extent of the repeated regions. For recombinant plasmids pTDN1-1010, pTDN1-1011 and pTDN1-1018 the closed bar indicates vector pHG327 whilst the open bar is the extent of inserted pTDN1; the broken arrow indicates the direction of transcription from the vector operator/promoter. The positions of Tn5 insertion for pTDN1-543 $(\nabla)$ and for pTDN1-511 $(\nabla)$ are indicated. Restriction enzyme abbreviations: H, HindIII; X, XhoI; E, EcoRI; B, BamHI; Sa, SalI; S, SmaI; Ss, SstI; Si, SinI; Bs, BstEII; Pv, PvuII; P, PstI.

Table 2. pTDN1 restriction fragments

\begin{tabular}{ccccccc}
\hline \hline & \multicolumn{7}{c}{ Designation and size (kbp) } \\
\cline { 2 - 7 } Enzyme $\ldots$ & HindIII & XhoI & EcoRI & BamHI & SalI & SmaI \\
\hline & HA & XA & EA & BA & SaA & SA \\
& $(51 \pm 1)$ & $(59 \pm 1)$ & $(51 \pm 1)$ & $(52 \pm 1)$ & $(52 \pm 1)$ & $(62 \pm 1)$ \\
HB & XB & EB & BB & SaB & SB \\
& $(12 \cdot 65)$ & $(7 \cdot 95)$ & $(19 \cdot 85)$ & $(9 \cdot 8)$ & $(13 \cdot 25)$ & $(8 \cdot 3)$ \\
HC & XC & EC & BC & SaC & SC \\
& $(9 \cdot 3)$ & $(6 \cdot 9)$ & $(3 \cdot 3)$ & $(7.0)$ & $(5 \cdot 4)$ & $(3 \cdot 5)$ \\
HD & XD & ED & BD & SaD & SD \\
& $(3 \cdot 65)$ & $(3 \cdot 2)$ & $(2 \cdot 8)$ & $(5 \cdot 0)$ & $(4 \cdot 5)$ & $(2 \cdot 3)$ \\
& HE(2) & XE & EE(2) & BE & SaE & SE \\
& $(1 \cdot 1)$ & $(1 \cdot 5)$ & $(0 \cdot 85)$ & $(4 \cdot 7)$ & $(2 \cdot 7)$ & $(1 \cdot 35)$ \\
& XF & & & SaF & SF \\
& $(0 \cdot 45)$ & & & $(0 \cdot 9)$ & $(1 \cdot 1)$ \\
& & & & SG \\
& & & & & $(0 \cdot 9)$ \\
\hline \hline
\end{tabular}


approaches ensures its integrity: $(a)$ single and double digestion of the native plasmid; $(b)$ cloning of fragments $\mathrm{HB}, \mathrm{HC}, \mathrm{HD}, \mathrm{HE}, \mathrm{XC}, \mathrm{XD}, \mathrm{XE}$ and EC, determination of their restriction profiles, and hybridization to variously digested pTDN $1 ;(c)$ restriction digestion of a variety of deletion mutants and pTDN1::Tn5 insertion mutants.

The region otherwise devoid of restriction enzyme sites contains a single $\operatorname{Sin} I$ site (Fig. 2). pTDN1-543 has Tn5 inserted approximately $8.85 \mathrm{kbp}$ into HA. By digestion of this mutant with $\operatorname{Sin} \mathrm{I}$, and double-digestion involving $\operatorname{Sin} \mathrm{I}$ and the other six enzymes, the region is effectively cut into three fragments. Allowing for the contribution of $\operatorname{Tn} 5$ (Jorgensen et al., 1979) the region was accurately sized.

Restriction site profuse region is bounded by direct repeats As the restriction map of pTDN1 was constructed analysis revealed that the HE clone (pTDN1-1012) and also the EC clone (pTDN1-1020) hybridized with fragments mapped several kilobases apart on the intact pTDN1. Fig. 3 shows examples of such hybridization.
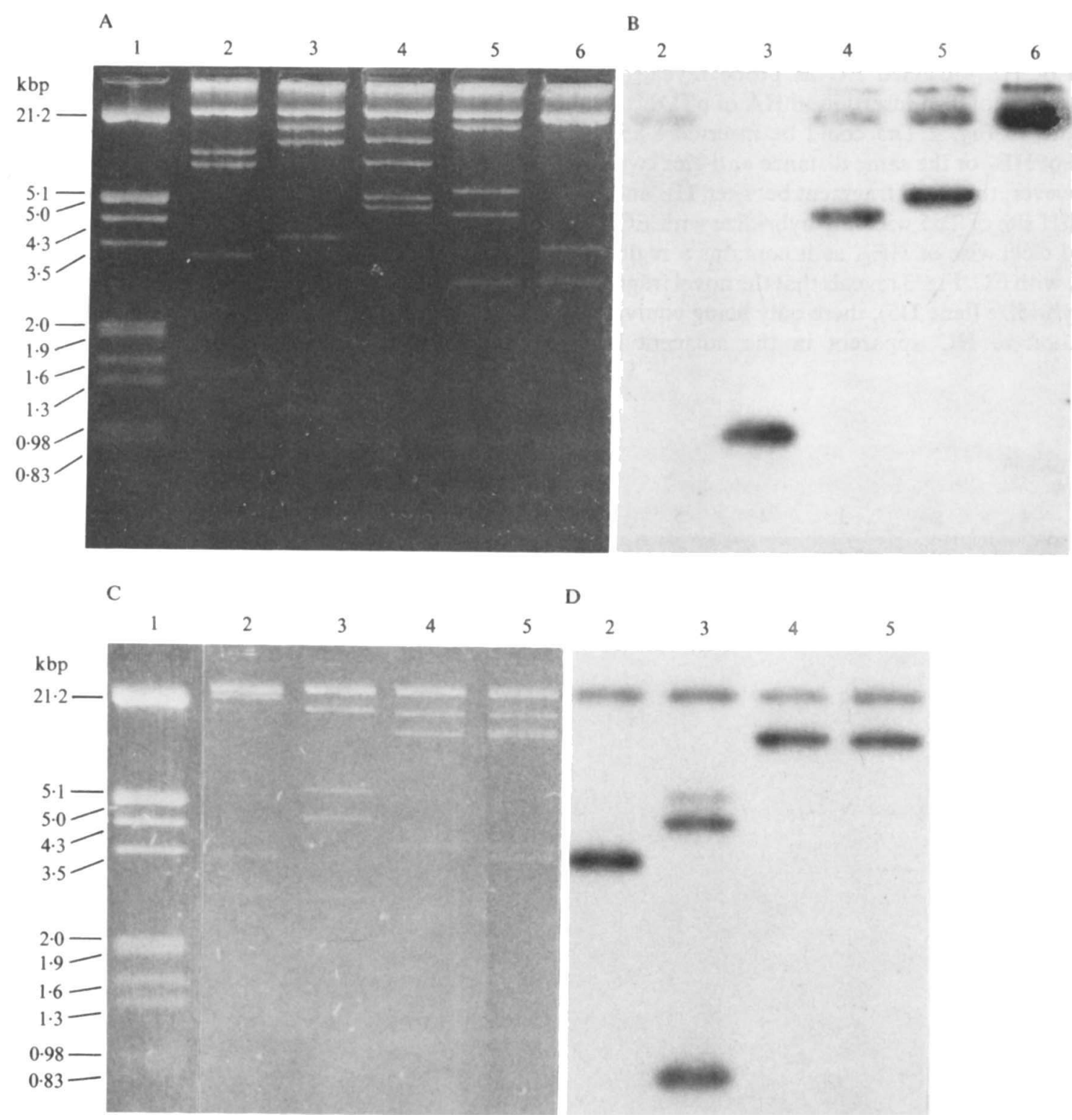

Fig. 3. Demonstration of repeated regions within plasmid pTDNI and the position of $\operatorname{Tn} 5$ insertion in pTDN1-543. A: lane 1, bacteriophage $\lambda$ DNA digested with HindIII/EcoRI; 2, pTDN1 XhoI; 3, pTDN1 HindIII; 4, pTDN1 BamHI; 5, pTDN1 SalI; 6, pTDN1 EcoRI. B, autoradiogram of the Southern blot of A probed with ${ }^{32} \mathrm{P}$-labelled pTDN1-1012 (bearing HE of pTDN1). C: lane 1, $\lambda$ HindIII/EcoRI; 2, pTDN1 EcoRI; 3, pTDN1 Sall; 4, pTDN1 HindIII; 5, pTDN1-543 HindIII. D, autoradiogram of the Southern biot of $\mathrm{C}$ probed with ${ }^{32} \mathrm{P}$-labelled pTDN1-1020 (bearing EC of pTDN1). 
Where HE was used as a probe, fragments XA (lane B2), HE (lane B3), BA and BE (lane B4), SaA and SaC (lane B5) and EA, EB and EE (lane B6) all showed hybridization. Where $\mathrm{EC}$ was the probe, fragments EA and EC (lane D2), SaA, SaC, SaD and SaF (lane D3) and HA and HC (lane D4) hybridized. Mapping data and hybridization suggested initially that the repeated region involved all of $\mathrm{HE}$ and at least part of EC up to and including SaF. Therefore, we could predict the presence of two $\mathrm{HE}\left(\mathrm{HE}_{\mathrm{L}}\right.$ and $\left.\mathrm{HE}_{\mathrm{R}}\right)$, two $\mathrm{EE}\left(\mathrm{EE}_{\mathrm{L}}\right.$ and $\left.\mathrm{EE}_{\mathrm{R}}\right)$ and possibly two SaF fragments (Fig. 2). pTDN1-1002 (containing $\mathrm{XC}$ ) revealed no hybridization with $\mathrm{HA}$, $\mathrm{XA}, \mathrm{BA}$ or EA (data not presented); therefore the repeated region ends before the first $X h o I$ site anticlockwise of $\mathrm{HE}_{\mathrm{L}}$. Cloned $\mathrm{EC}$ as probe revealed the relative position of $\mathrm{Tn} 5$ insertion in HA of pTDN1-543. With regard to Fig. 2 Tn 5 could be inserted $8.85 \mathrm{kbp}$ clockwise of $\mathrm{HE}_{\mathrm{L}}$ or the same distance anti-clockwise of $\mathrm{HE}_{\mathrm{R}}$. However, the novel fragment between $\mathrm{HE}$ and the first HindIII site of Tn5 will only hybridize with EC if it is situated clockwise of $\mathrm{HE}_{\mathrm{L}}$, as it contains a region of homology with EC. Fig. 3 reveals that the novel fragment did not hybridize (lane D5), there only being equivalent hybridization to $\mathrm{HC}$ apparent in the adjacent lane.
Therefore, $\operatorname{Tn} 5$ is situated anticlockwise of $\mathrm{HE}_{\mathrm{R}}$ in pTDN1-543.

Growth of UCC22 (which carries pTDN1) on benzoate minimal medium resulted in rapid loss of the ability to utilize $m$-toluate and aromatic amines, $\mathrm{Tdn}^{-}$cells remaining white when sprayed with catechol. When such 'benzoate-cured' derivatives were analysed they were all found to contain an identical deleted pTDN1 plasmid which retained HA and HE and EA and EE. A representative isolate was retained and termed $\mathrm{UCC} 23$ containing pTDN1-3. Equivalent concentrations of pTDN1 and pTDN1-3 were hybridized against a mixture of the HC clone (pTDN1-1016) and the HE clone (pTDN1-1012) (Fig. 4). Computer-aided image analysis of the resulting autoradiograph revealed approximately twice the density and area of hybridization for HE (lane B3) and EE (lane B5) of pTDN1 when compared to equivalent pTDN1-3 bands (lanes B2 and B4). Hybridization also revealed the absence of $\mathrm{SaF}$ from pTDN1-3 (lane B6). Therefore, an absolute boundary for the repeated region is given by $\mathrm{L}$ terminating before $\mathrm{XC}$ and $\mathrm{R}$ starting in $\mathrm{SaF}$ and the distribution of restriction sites suggest it is a direct repeat. The deletion seen in pTDN1-3 is a direct recombinational loss of approxi-

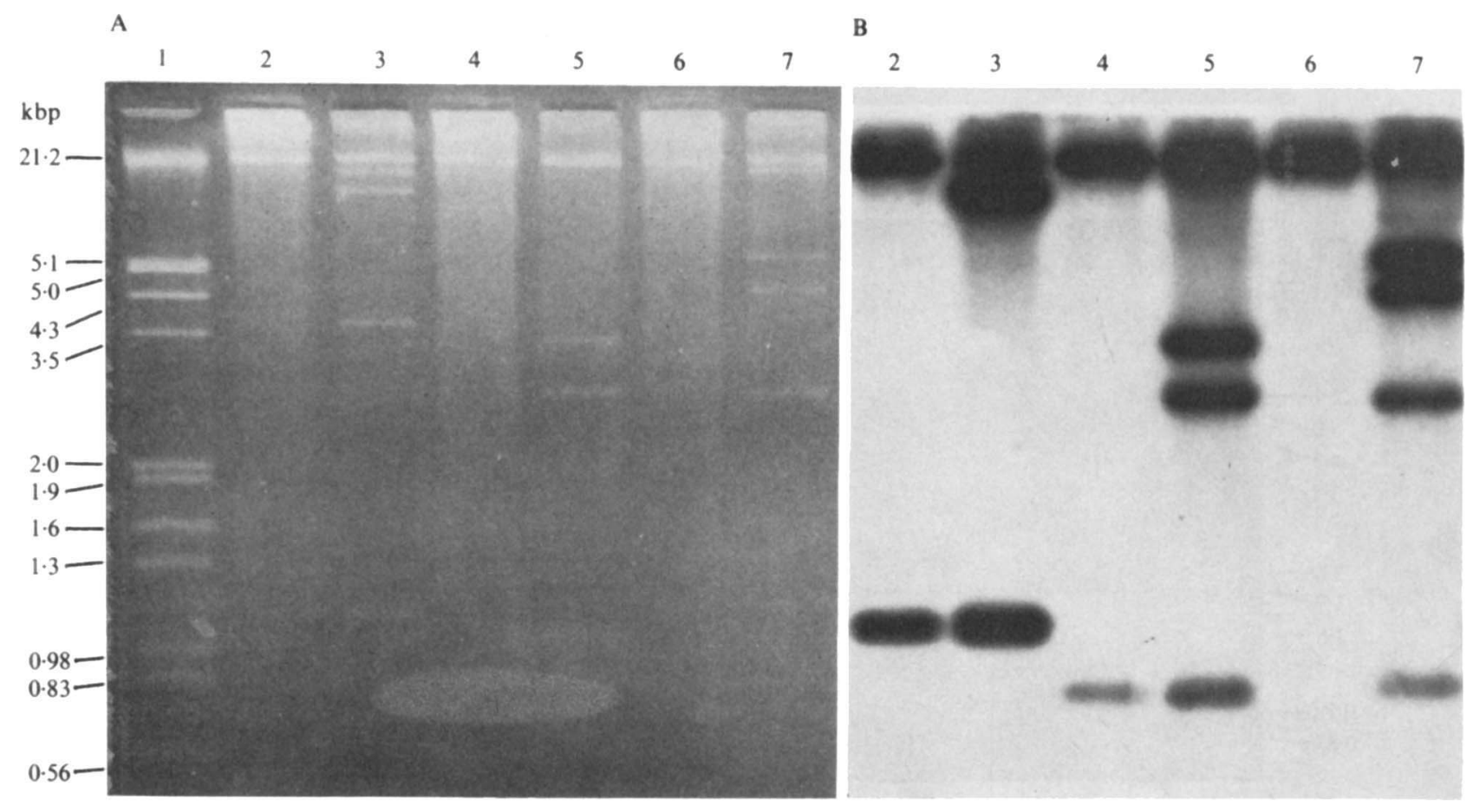

Fig. 4. Demonstration that deletion in pTDN1-3 occurs between direct repeats, one copy of the repeated region being retained. A: lane 1, $\lambda$ HindIII/EcoRI; 2, pTDN1-3 HindIII; 3, pTDN1 HindIII; 4, pTDN1-3 EcoRI; 5, pTDN1 EcoRI; 6, pTDN1-3 SalI; 7, pTDN1 SaII. B, autoradiogram of the Southern blot of A probed with 32P-labelled pTDN1-1012 (bearing HE of pTDN1) and pTDN1-1016 (bearing $\mathrm{HC}$ of pTDN1). 
mately $26 \mathrm{kbp}$ with one copy of the direct repeat being retained.

\section{Location of catabolic genes}

We knew from a previous study (McClure \& Venables, 1987) that XB contained a C23O gene. HD is within XB (Fig. 2). pTDN1-1010 and pTDN1-1011 were constructed containing HD in opposite orientations. Transformation of either of these constructs into E. coli $\mathrm{JM} 107$ resulted in transformants which showed $\mathrm{C} 23 \mathrm{O}$ activity as adjudged by the catechol spray test. pTDN1-1010 was digested with SstI and religated to give pTDN1-1018 which also exhibited $\mathrm{C} 23 \mathrm{O}$ activity in $E$. coli JM107. The Tn 5 insert in pTDN1-511 is a further $0.2 \mathrm{kbp}$ downstream of the $S s t$ I site utilized in the construction of pTDN1-1018, but the plasmid still confers an active $\mathrm{C} 23 \mathrm{O}$. This locates the $\mathrm{C} 23 \mathrm{O}$ gene to a $1.9 \mathrm{kbp}$ region of HD (Fig. 2). A fine restriction endonuclease map of HD revealed no restriction site homology to previously described clones bearing $\mathrm{C} 23 \mathrm{O}$ genes (Chatfield \& Williams, 1986).

We have cloned $\mathrm{HB}$ in both orientations to give pTDN1-1014 and pTDN1-1015. When these two plasmids were mobilized into $P$. putida KT2442 using pNJ5000, pTDN1-1014 conferred the ability to grow on aniline but not $m$-toluate or $p$-toluidine whereas pTDN11015 failed to confer the ability to grow on any of these substrates. The products of TO and dihydroxycyclohexa- diene carboxylate dehydrogenase (DHCDH) activity on aniline is catechol which may be further metabolized via a chromosomal ortho-cleavage pathway in $P$. putida KT2442. This suggests the presence of at least these two genes on $\mathrm{HB}$ expressed only in an orientation reading from the $\mathrm{HE}_{\mathrm{L}}$ end of $\mathrm{HB}$.

Fifteen pTDN1::Tn5 mutants were obtained in $P$. putida KT2442, and showed the phenotypes indicated in Fig. 5. All insertions which affected $m$-toluate and aromatic amine degradation were situated within a $15 \mathrm{kbp}$ section of the region deleted in pTDN1-3. Most insertions caused loss of all phenotypes and from our knowledge of pathways coded on pTDN1 and $P$. putida KT2442 chromosome we can suggest possible explanations. The inserts in HB are likely to be in and around TO and any polar effect on subsequent meta-pathway genes could explain complete loss of phenotype. Mutations affecting positive regulators of the pathway could cause complete loss of phenotype; thus the group of inserts in $\mathrm{HC}$ could be regulatory. pTDN1-511 in KT2442 confers weak growth on $p$-toluidine and $m$-toluate and normal growth on aniline. This probably indicates fully functional TO and DHCDH genes (situated on HB); the product of the enzymes encoded by these genes can be further metabolized via the chromosomal ortho-cleavage pathway. The gene order for the meta-cleavage pathway on pTDN1 may be different to that found on TOL plasmids as there is a gap of at least $2 \mathrm{kbp}$ between the accurately mapped position of the $\mathrm{C} 23 \mathrm{O}$ on $\mathrm{HD}$ and the TO/DHCDH functions on HB.

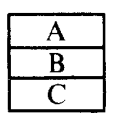<smiles>Cc1cccc(C(=O)O)c1</smiles>

A, $m$-toluate<smiles>Cc1ccc(N)cc1</smiles>

B, p-toluidine<smiles>Nc1ccccc1</smiles>

$\mathrm{C}$, aniline

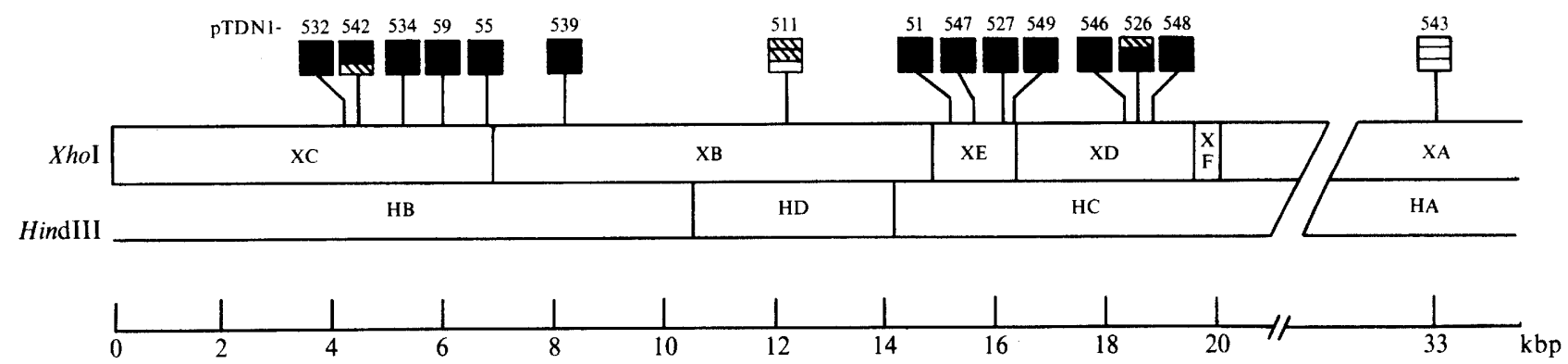

Fig. 5. pTDN1 : :Tn5 mutants of $P$. putida KT2442. The mapped position of insertion of Tn 5 for plasmids pTDN1-51 to pTDN1-549 aiong with the relevant phenotype of the host strain is indicated. An open bar indicates a normal phenotype while a hatched bar indicates weak growth on the substrate. A closed bar indicates no growth on the substrate although some of these mutants show high reversion frequencies $\left(>10^{-6}\right.$ per cell). 


\section{Origin of $p T D N 1$}

To test the hypothesis that pTDN1 originated from the chromosome of $P$. putida mt-2, and to check for any homology with TOL plasmids, the following hybridizations were done. Initially, pTDN1-1000 (pNCM1), known to contain a functional $\mathrm{C} 23 \mathrm{O}$ gene derived from pTDN1, was used as a radiolabelled probe against $\mathrm{XhoI-}$ digested chromosomal DNA from UCC23 and two isogenically related strains KT2440 and PaW130, derived from $P$. putida mt-2. Additionally, pTDN1-1000 was probed against plasmids carrying previously characterized C23O genes, pWW15-3151 (C23OI), pWW153161 (C23OII), and pWW15, the parent plasmid of these $\mathrm{C} 23 \mathrm{O}$ genes. In no case was hybridization detectable (data not presented). Intact pTDN1 was then probed against digested pWW0, pWW15 and chromosomal DNA from UCC23, KT2440 and PaW130 (Fig. 6). Some hybridization was evident with XhoIE (XE, lane B3) and HindIIIA (HA, lane B4) fragments of pWW0 and Xh (lane B5) and BamHI h/i (Bh/i, lane B6) of pWW15, but only after prolonged (14 d) autoradiograph exposure, suggesting weak homology. We attribute smeared background hybridization involving chromosomal digests (lanes B7, 8 and 9) to slight chromosomal contamination of the probe DNA, evident only on prolonged exposure. We conclude that pTDN1 did not originate from the chromosome of $P$. putida $\mathrm{mt}-2$.

\section{Discussion}

A complete restriction map of plasmid pTDN1 has been obtained, and its size has been determined as $79 \pm 1 \mathrm{kbp}$. The restriction sites are localized to a region of about $28 \mathrm{kbp}$, the extremities of which comprise repeated nucleotide sequences in direct orientation. This region also appears to contain the degradative genes of pTDN1. The region of about $51 \mathrm{kbp}$ which lies outside the direct repeats is devoid of restriction sites for the enzymes HindIII, XhoI, EcoRI, BamHI, SalI and SmaI, and also for a further nine hexanucleotide-recognizing enzymes which we have not used for accurate mapping. Similarly, Hooper et al. (1989) have described a 4chlorobiphenyl catabolic plasmid of $53 \mathrm{kbp}$ with most restriction enzyme sites clustered in a $5 \mathrm{kbp}$ region. It has been suggested that clustering of restriction enzyme sites in regions which determine phenotype, and scarcity in regions which determine replication and self-transfer, reflect evolution to broad host-range, and restrictionsite-rich regions represent recently acquired genes (Meyer et al., 1977; Meyer \& Shapiro, 1980). Several of our pTDN1::Tn5 derivatives transfer, replicate and show catabolic activity in $E$. coli but the full breadth of pTDN1 host-range has not been determined.

It is likely that the catabolic genes required for aromatic amine and $m$-toluate degradation are located in the region of pTDN1 between the direct repeats. This

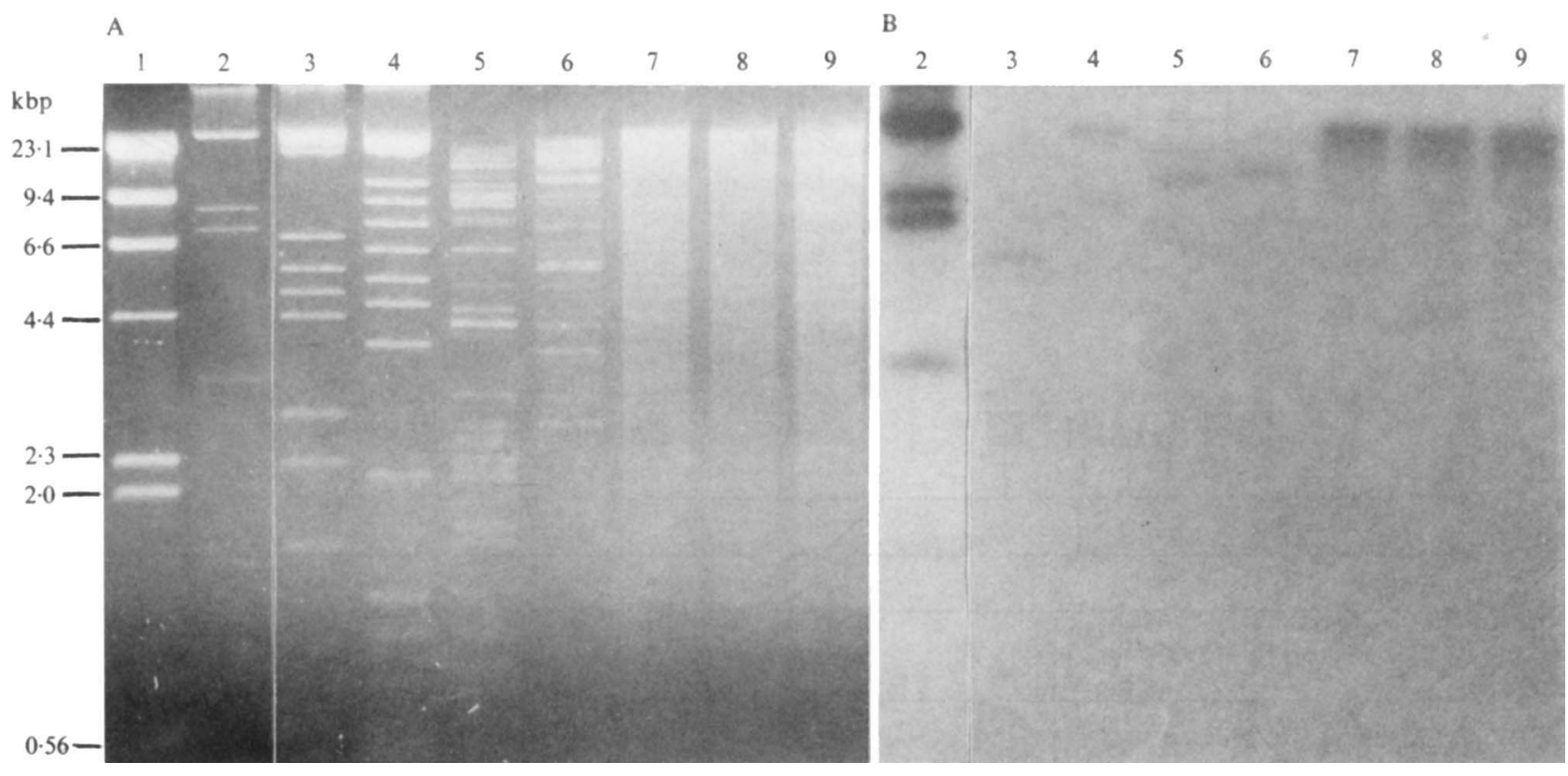

Fig. 6. DNA-DNA hybridization homology of radiolabelled pTDN1 with pWW0, pWW15, and chromosomal DNA of UCC23, KT2440 and PaW130. A: lane 1, $\lambda$ HindIII; 2, pTDN1 XhoI; 3, pWW0 XhoI ; 4, pWW0 HindIII; 5, pWW15 XhoI ; 6, pWW15 BamHI; 7, UCC23 XhoI; 8, KT2440 XhoI; 9, PaW130 XhoI. B, autoradiogram of the Southern blot of A probed with ${ }^{32}$ P-labelled pTDN1. 
conclusion is supported by several observations: (i) deletions of the region between the repeats, as in pTDN1-3, causes complete loss of degradative ability; (ii) all $\operatorname{Tn} 5$ insertions which produce loss of degradative ability are located in this region; (iii) the $\mathrm{C} 23 \mathrm{O}$, TO and $\mathrm{DHCDH}$ genes have been cloned on fragments from this region.

The distribution of $\operatorname{Tn} 5$ insertions in pTDN 1 is instructive. The method used for $\operatorname{Tn} 5$ mutagenesis was not selective for loss of $\mathrm{Tdn}^{+}$phenotype, but was selective for retention of replication and conjugal transfer. As all but one of the insertions obtained were in the catabolic region (representing only one-third of the plasmid) it can be inferred that the bulk of the noncatabolic region is occupied by replication and transfer functions.

Previous studies have indicated, on the basis of genetic homology and substrate specificity, that $\mathrm{C} 23 \mathrm{O}$ enzymes can be categorized as either of two types, C23OI and C23OII, though the former category can be subdivided on the basis of some differences in internal restriction sites (Keil et al., 1985a; Chatfield \& Williams, 1986; Harayama et al., 1987; Ghosal et al., 1987). The substrate specificity of the C23O from pTDN1 is similar to that of C23OII (McClure \& Venables, 1987), but its lack of restriction and hybridization homology suggest it is unrelated to either C23OI or C23OII. Although the $\mathrm{C} 23 \mathrm{O}$ proteins from $\mathrm{pTDN} 1$ and $\mathrm{pWW} 0$ are tetramers of similar molecular mass only four of the first 36 amino acid residues so far sequenced correspond (S. Chapman, personal communication; Nakai et al., 1983). We are currently determining the nucleotide sequence of the C23O gene from pTDN1.

Biochemical evidence indicates that the meta-cleavage pathway of pTDN1 comprises enzymes isofunctional to those of TOL plasmids (McClure \& Venables, 1986). There is strong evidence to support the theory of a common ancestry for the meta-pathways of a variety of TOL plasmids (Keil et al., 1985b; Shaw \& Williams, 1988) and NAH plasmids (Farrell \& Chakrabarty, 1979; Lehrbach et al., 1983; Cane \& Williams, 1986; Assinder \& Williams, 1988). Within catabolic-coding regions there is preservation of gene order, and restriction and hybridization homology. In view of this, it is surprising that there is little homology between the meta-cleavage pathway genes of pTDN1 and those of the TOL plasmids pWW15 and pWW0. Our results show only weak hybridization of pTDN1 with the XE and HA fragments of $\mathrm{pWW} 0$. XE is within HA and carries genes $x y l G, x y l F$, $x y l J$ and $x y l I$ (Franklin et al., 1983; Harayama et al., 1984) and presumably one or more of these genes have some homology with an analogous region of pTDN1. The same results and conclusions apply in the case of hybridizations between pTDN1 and pWW15.
The presence in pTDN1 of direct repeat sequences which flank the region containing the catabolic genes, and the deletion of this region during growth on benzoate, parallels the situation in the TOL plasmid pWW0 (Bayley et al., 1977; Meulien et al., 1981). Deletions between homologous sequences have been shown to occur within other catabolic plasmids: in an isopropylbenzene-degrading plasmid pRE4 (Eaton \& Timmis, 1986), and in a 3-chlorobenzoate-degrading plasmid pBR60 (Wyndham \& Straus, 1988), although in both cases the sequences are less-well-characterized than in pWW0. pBR60 was isolated from Alcaligenes sp. BR60 and shows marked instability, readily yielding mutants which no longer utilize 3-chlorobenzoate. The loss of phenotype has been correlated to a $14 \mathrm{kbp}$ deletion in pBR60 which occurs between two directly repeating regions (Wyndham et al., 1988). The direct repeats of pBR60 show remarkable restriction homology to those of pTDN1. This is in contrast to the $1.4 \mathrm{kbp}$, direct repeats of pWW0 which show no restriction or hybridization homology to pTDN1. The direct repeats of pTDN1 are also considerably larger than this: the minimum size is dictated by a SalI site to the left and a HindIII site to the right, with regard to Fig. 2, with the strong hybridization of EC to EA suggesting that lefthand termination is well into $\mathrm{SaF}$, but actually finishes before the second SalI site. Taken together, these data indicate a length in excess of $2 \mathrm{kbp}$. Most IS elements thus far described are less than $2 \mathrm{kbp}$ in size (Kleckner, 1981; Iida et al., 1983; Grindley, 1985). However, Barsomian \& Lessie (1986) and Gaffney \& Lessie (1987) describe rearrangements of pTGL1 and pTGL6 in $P$. cepacia mediated by several IS elements, one of which, IS 408 , is $2.7 \mathrm{kbp}$ in size. IS elements may promote replicon fusion which can occur due to the formation of a cointegrate during transposition (Shapiro, 1979). The entire donor replicon is inserted into the target and the transposon itself is duplicated. This cointegrate is subsequently resolved by recombination to give one copy of the element in the donor and recipient (Grindley, 1985). However, if resolution does not occur then a cointegrate consisting of donor/recipient bounded by two copies of the IS element can persist. Such cointegrates, bearing an additional copy of the IS element, were seen by Barsomian \& Lessie (1986). Tn4652, a $17 \mathrm{kbp}$ transposon derived from TOL plasmid pWW0, also forms such cointegrates (Tsuda \& Iino, 1987) and resolution was found to be weak when compared to that of Tn3 (De La Cruz \& Grinstead, 1982) such that 90$95 \%$ of cells still carried a cointegrate after 1 week of culture. It is possible that pTDN1 arose by a similar cointegrate event mediated by a transposon/insertion element.

The origin of pTDN1 remains obscure. However, 
hybridization studies with the chromosome of UCC23 and related strains have yielded some clues. Chromosomal digests of UCC23 always had a profile identical to those of PaW130 and KT2440. Therefore, the original bacterial isolate bearing pTDN1 was derived from $\mathrm{PaW} 1$. We have tried to repeat the adaptation of McClure \& Venables (1986) using $p$-toluidine and aniline at 1,2 and $5 \mathrm{mM}$ concentrations, and $\mathrm{PaW} 1$ from various sources as well as derivatives PaW8, KT2440 and PaW130, without success. We conclude that pTDN1 arose from an external source during the original adaptation or was present in some form in the original $\mathrm{PaW} 1$ culture used. This fact does not detract from the nature of pTDN1 which is clearly a uniquely described plasmid.

The following paper (Saint \& Venables, 1990) describes factors affecting the stability of the Tdn phenotype in various $P$. putida hosts bearing pTDN1.

C.P.S. was supported by SERC Fellowship GR/E49531 awarded to W.A.V.

\section{References}

Anson, J. G. \& Mackinnon, G. (1984). Novel Pseudomonas plasmid involved in aniline degradation. Applied and Environmental Microbiology 48, 868-869.

Assinder, S. J. \& Williams, P. A. (1988). Comparison of the meta pathway operons on NAH plasmid pWW60-22 and TOL plasmid pWW53-4 and its evolutionary significance. Journal of General Microbiology 134, 2769-2778.

BaChMANN, B. J. (1987). Derivations and genotypes of some mutant derivatives of Escherichia coli K12. In Escherichia coli and Salmonello typhimurium: Cellular and Molecular Biology, pp. 1190-1219. Edited by F. C. Neidhardt, J. L. Ingraham, K. Brooks Lowe, B. Magasanik, M. Schaechter \& H. E. Umbarger. Washington, DC: American Society for Microbiology.

Bagdasarian, M., Lurz, R., Rückert, B., Franklin, F. C. H., Bagdasarian, M. M., Frey, J. \& Timmis, K. N. (1981). Specificpurpose cloning vectors. II. Broad host range, high copy number RSF1010-derived vectors and a host: vector system for gene cloning. Gene 16, 237-247.

Barsomian, G. \& Lessie, T. G. (1986). Replicon fusions promoted by insertion sequences on Pseudomonas cepacia plasmid pTGL6. Molecular and General Genetics 204, 273-280.

Bayley, S. A., Duggleby, C. J., Worsey, M. J., Williams, P. A., HARDY, K. J. \& BRODA, P. (1977). Two modes of loss of the TOL function from Pseudomonas putida mt-2. Molecular and General Genetics 154, 203-204.

BIRNBOIM, H. \& DoLY, J. (1979). A rapid alkaline extraction procedure for screening recombinant plasmid DNA. Nucleic Acids Research 7, 1513-1523.

Boulnois, G. J., Varley, J. M., Sharpe, G. S. \& Franklin, F. C. H. (1985). Transposon donor plasmids based on colIb-P9, for use in Pseudomonas putida and a variety of other Gram negative bacteria. Molecular and General Genetics 200, 65-67.

CANe, P. A. \& Williams, P. A. (1986). A restriction map of naphthalene catabolic plasmid pWW60-1 and the location of some of its catabolic genes. Journal of General Microbiology 132, 2919-2929.

Chatfield, L. K. \& Williams, P. A. (1986). Naturally occurring TOL plasmids in Pseudomonas strains carry either two homologous or two non-homologous catechol-2,3-oxygenase genes. Journal of Bacteriology 168, 878-885.
Cohen, S. N., Chang, A. C. Y. \& Hsu, C. L. (1972). Non-chromosomal antibiotic resistance in bacteria: genetic transformation of Escherichia coli by R factor DNA. Proceedings of the National Academy of Sciences of the United States of America 69, 2110-2114.

De La Cruz, F. \& Grinstead, J. (1982). Genetic and molecular characterization of $\mathrm{Tn} 21$, a multiple resistance transposon from R100.1. Journal of Bacteriology 151, 222-228.

EATON, R. W. \& RIBBONS, D. W. (1982). Metabolism of dibutylphthalate and phthalate by Micrococcus sp. strain 12B. Journal of Bacteriology 151, 48-57.

Eaton, R. W. \& Timmis, K. N. (1986). Spontaneous deletion of a 20 kilobase DNA segment carrying genes specifying isopropyl-benzene metabolism in Pseudomonas putida RE204. Journal of Bacteriology 168, 428-430.

Farrell, R. \& Chakrabarty, A. M. (1979). Degradative plamids molecular nature and mode of evolution. In Plasmids of Medical Environmental and Commercial Importance, pp. 97-109. Edited by K. N. Timmis \& A. Puhler. Amsterdam: Elsevier/North Holland Biomedical Press.

Franklin, F. C. H., Bagdasarian, M., Bagdasarian, M. M. \& TIMmIs, K. N. (1981). Molecular and functional analysis of the TOL plasmid pWW0 from Pseudomonas putida and cloning of genes for the entire regulated aromatic ring meta cleavage pathway. Proceedings of the National Academy of Sciences of the United States of America 78, 7458-7462.

Franklin, F. C. H., Lehrbach, P. R., Lurz, R., Rueckert, B., BAgDasarian, M. \& Timmis, K. N. (1983). Localization and functional analysis of transposon mutations in regulatory genes of the TOL catabolic pathway. Journal of Bacteriology 154, 676-685.

GAFFNEY, T. D. \& LESSIE, T. G. (1987). Insertion sequence dependent rearrangements of Pseudomonas cepacia plasmid pTGL2. Journal of Bacteriology 169, 224-230.

GASSON, M. J. \& WILLETTS, N. S. (1977). Further characterization of the F fertility inhibition systems of "unusual" Fin ${ }^{+}$plasmids. Journal of Bacteriology 131, 413-420.

Ghosal, D., You, I.-S. \& Gunsalus, I. C. (1987). Nucleotide sequences and expression of gene $n a h H$ of plasmid NAH7 and homology with gene $x y / \mathrm{E}$ of TOL pWW0. Gene 55, 19-28.

GRINDLEY, N. D. F. (1985). Transpositional recombination in prokaryotes. Annual Review of Biochemistry 54, 863-896.

GriNTER, N. J. (1983). A broad host range cloning vector transposable to various replicons. Gene 21, 133-143.

Guerry, P., Le Blanc, D. J. \& FalKow, S. (1973). General method for isolation of plasmid deoxyribonucleic acid. Journal of Bacteriology 116, 1064-1066.

Harayama, S., Lehrbach, P. R. \& Timmis, K. N. (1984). Transposon mutagenesis analysis of meta-cleavage pathway operon genes of the TOL plasmid of Pseudomonas putida mt-2. Journal of Bacteriology 160, 251-255.

Harayama, S., RekiK, M., Wasserfallen, A. \& Bairoch, A. (1987). Evolutionary relationships between catabolic pathways for aromatics: conservation of gene order and nucleotide sequences of catechol oxidation genes of pWW0 and NAH7 plasmids. Molecular and General Genetics 210, 241-247.

Holmes, D. S. \& Quigley, N. (1981). A rapid boiling method for preparation of bacterial plasmids. Analytical Biochemistry 114, 193197.

HoOper, S. W., Dockenforff, T. C. \& SAyler, G. S. (1989). Characteristics and restriction analysis of the 4-chlorobiphenyl catabolic plasmid, pSS50. Applied and Environmental Microbiology 55, 1286-1288.

IIDA, S., MeYER, J. \& ARBER, W. (1983). Prokaryotic IS elements. In Mobile Genetic Elements, pp. 161-221. Edited by J. Shapiro. New York: Academic Press.

JORGENSEN, R. A., Rothstein, S. J. \& REZNIKOFF, W. S. (1979). A restriction enzyme cleavage map of $\operatorname{Tn} 5$ and location of a region encoding neomycin resistance. Molecular and General Genetics 177, 65-72.

KeIL, H. \& Williams, P. A. (1985). A new class of TOL plasmid deletion mutants in Pseudomonas putida MT15 and their reversion by tandem gene amplification. Journal of General Microbiology 131, 1023-1033. 
Keil, H., Lebens, M. R. \& Williams, P. A. (1985a). TOL plasmid pWW15 contains two non-homologous independently regulated catechol-2,3-oxygenase genes. Journal of Bacteriology 163, 248-255.

Keil, H., Keil, S., PickuP, R. W. \& Williams, P. A. (1985b). Evolutionary conservation of genes coding for meta-pathway enzymes within TOL plasmids pWW0 and pWW53. Journal of Bacteriology 164, 887-895.

KLECKNER, N. (1981). Transposable elements in prokaryotes. Annual Review of Genetics 15, 341-404.

KUSHNER, S. R. (1978). An improved method for transformation of Escherichia coli with ColEI derived plasmids. In Genetic Engineering, pp. 17-23. Edited by H. B. Boyer \& S. Nicoza. Amsterdam: Elsevier.

Lehrbach, P. R., MCGRegoR, I., WARD, J. M. \& BRODA, P. (1983). Molecular relationships between Pseudomonas IncP-9 degradative plasmids TOL, NAH, and SAL. Plasmid 10, 164-174.

McClure, N. C. \& Venables, W. A. (1986). Adaptation of Pseudomonas putida mt-2 to growth on aromatic amines. Journal of General Microbiology 132, 2209-2218.

MCClure, N. C. \& Venables, W. A. (1987). pTDN1, a catabolic plasmid involved in aromatic amine catabolism in Pseudomonas putida mt-2. Journal of General Microbiology 133, 2073-2077.

MEYer, R. J., Figurski, D. \& Helinski, D. R. (1977). Properties of the plasmid RK2 as a cloning vehicle. In DNA Insertion Elements, Plasmids and Episomes, pp. 559-566. Edited by A. I. Bukhari, J. A. Shapiro \& S. L. Adhya. Cold Spring Harbor, NY: Cold Spring Harbor Laboratory.

MEYER, R. J. \& ShapIRo, J. A. (1980). Genetic organization of the broad host-range IncP-1 plasmid R751. Journal of Bacteriology 143, 1362-1373.

Meulien, P., Downing, R. G. \& Broda, P. (1981). Excision of the $40 \mathrm{~kb}$ segment of the TOL plasmid from Pseudomonas putida $\mathrm{mt}-2$ involves direct repeats. Molecular and General Genetics 184, 97-101.

Murray, K., Duggleby, C. J., Sala-Trepat, J. M. \& Williams, P. A. (1972). The metabolism of benzoate and methyl benzoates via the meta-cleavage pathway by Pseudomonas arvilla mt-2. European Journal of Biochemistry 28, 301-310.

NakaI, C., Hori, K., KagamiYama, H., Nakazawa, T. \& Nozaki, M. (1983). Purification, subunit structure, and partial amino acid sequence of metapyrocatechase. Journal of Biological Chemistry 258, $2916-2922$.
SAINT, C. P. \& Venables, W. A. (1990). Loss of Tdn catabolic genes by deletion from and curing of plasmid pTDN1 in Pseudomonas putida: rate and mode of loss are substrate and $\mathrm{pH}$ dependent. Journal of General Microbiology 136, 627-636.

ShapIRo, J. A. (1979). Molecular model for the transposition and replication of bacteriophage $\mathrm{Mu}$ and other transposable elements. Proceedings of the National Academy of Sciences of the United States of America 76, 1933-1937.

Shaw, L. E. \& Williams, P. A. (1988). Physical and functional mapping of two cointegrate plasmids derived from RP4 and TOL plasmid pDK1. Journal of General Microbiology 134, 2463-2474.

SOUTHERN, E. M. (1975). Detection of specific sequences among DNA fragments separated by gel electrophoresis. Journal of Molecular Biology 98, 503-517.

Stewart, G. S. A. B., Lubinski-Mink, S., Jackson, C. G., Cassel, A. \& KUHN, J. (1986). pHG165: a pBR322 copy number derivative of pUC8 for cloning and expression. Plasmid 15, 172-181.

TsudA, M. \& IINo, T. (1987). Genetic analysis of a transposon carrying toluene degrading genes on a TOL plasmid pWW0. Molecular and General Genetics 210, 270-276.

Wheatcroft, R. \& Williams, P. A. (1981). Rapid methods for the study of both stable and unstable plasmids in Pseudomonas. Journal of General Microbiology 124, 433-437.

Williams, P. A. \& MurRay, K. (1974). Metabolism of benzoate and the methyl benzoates by Pseudomonas putida (arvilla) mt-2: evidence for the existence of a TOL plasmid. Journal of Bacteriology 120, $416-423$.

Worsey, M. J. \& Williams, P. A. (1975). Metabolism of toluene and xylenes by Pseudomonas putida (arvilla) $\mathrm{mt}-2$ : evidence for a new function of the TOL plasmid. Journal of Bacteriology 124, 7-13.

WYNDHAM, R. C. \& Straus, N. A. (1988). Chlorobenzoate catabolism and interactions between Alcaligenes and Pseudomonas species from Bloody Run Creek. Archives of Microbiology 150, 230-236.

Wyndham, R. C., Singh, R. K. \& Straus, N. A. (1988). Catabolic instability plasmid gene deletion and recombination in Alcaligenes sp. BR60. Archives of Microbiology 150, 237-243.

Yanisch-Perron, C., Vieira, J. \& Messing, J. (1985). Improved M13 phage cloning vectors and host strains: nucleotide sequences of the M13mp18 and pUC19 vectors. Gene 33, 103-119. 